\title{
Role of Oxytocin/Vasopressin-Like Peptide and Its Receptor in Vitellogenesis of Mud Crab
}

\author{
Dongdong Lin, Yujie Wei and Haihui Ye * \\ College of Ocean and Earth Sciences, Xiamen University, Xiamen 361102, China; \\ 22320171150801@stu.xmu.edu.cn (D.L.); 22320181152145@stu.xmu.edu.cn (Y.W.) \\ * Correspondence: haihuiye@xmu.edu.cn
}

Received: 2 March 2020; Accepted: 23 March 2020; Published: 26 March 2020

\begin{abstract}
Oxytocin (OT)/vasopressin (VP) signaling system is important to the regulation of metabolism, osmoregulation, social behaviours, learning, and memory, while the regulatory mechanism on ovarian development is still unclear in invertebrates. In this study, Spot/vp-like and its receptor (Spot/vpr-like) were identified in the mud crab Scylla paramamosain. Spot/vp-like transcripts were mainly expressed in the nervous tissues, midgut, gill, hepatopancreas, and ovary, while Spot/vpr-like were widespread in various tissues including the hepatopancreas, ovary, and hemocytes. In situ hybridisation revealed that Spot/vp-like mRNA was mainly detected in 6-9th clusters in the cerebral ganglion, and oocytes and follicular cells in the ovary, while Spot/vpr-like was found to localise in F-cells in the hepatopancreas and oocytes in the ovary. In vitro experiment showed that the mRNA expression level of Spvg in the hepatopancreas, Spvgr in the ovary, and 17 $\beta$-estradiol $\left(E_{2}\right)$ content in culture medium were significantly declined with the administration of synthetic SpOT/VP-like peptide. Besides, after the injection of SpOT/VP-like peptide, it led to the significantly reduced expression of Spvg in the hepatopancreas and subduced $\mathrm{E}_{2}$ content in the haemolymph in the crabs. In brief, $S p \mathrm{OT} / \mathrm{VP}$ signaling system might inhibit vitellogenesis through neuroendocrine and autocrine/paracrine modes, which may be realised by inhibiting the release of $E_{2}$.
\end{abstract}

Keywords: oxytocin/vasopressin; vitellogenesis; $17 \beta$-estradiol; mud crab

\section{Introduction}

Oxytocin (OT) and vasopressin (VP), the most ancient neuropeptides, were discovered from mammalian posterior pituitary in the early 1920s, having the oxytocic action or causing an increase in blood pressure [1]. Subsequently, they were purified and sequenced in 1953 before any other neuropeptides, and their preprohormones were firstly cloned from a rat genomic library in the early 1980s [2-4].

In mammals, the genes of OT and VP lie in the same chromosome towards each other, possessing a highly similar structure: a nonapeptide, located after a signal peptide and followed by a dibasic cleavage site and a neurophysin. The two nonapeptides both display a ring-like structure with an intramolecular disulfide bond (Cys1-Cys6), discriminated at position 8 where there is a neutral amino acid for OT, but a basic for VP [5,6]. And the neurophysin, with 14 cysteine residues, is an OT/VP-carrier protein which is essential to fold and sort the prohormones [7]. OT and VP are synthesised by the neurosecretory cells of supraoptic and paraventricular nucleus in hypothalamus and transported to the posterior pituitary via axons for secretion, which are multifunctional with essential roles in the regulation of social and reproductive behavior [8,9]. OT is mainly involved in inducing uterine contraction during parturition and milk ejection during lactation, and affecting parental care, social cognition, learning and memory [9-11], while VP is related to parental care, male/female pair bonding, blood pressure control and antidiuretic actions by stimulating water reabsorption via the renal collecting ducts [12]. 
The functions of OT/VP are mediated by the four receptors belonging to a family of $G$ protein-coupled receptors (OTR, $V_{1 a} R, V_{1 b} R$ and $V_{2} R$ ) [13]. Among them, OTR, $V_{1 a} R$ and $V_{1 b} R$ all couple to the inositol trisphosphate $\left(\mathrm{IP}_{3}\right) / \mathrm{Ca}^{2+}$ signal transduction pathway, while $\mathrm{V}_{2} \mathrm{R}$ regulates the level of intracellular cAMP by the coupled adenylate cyclase [14-17]. Besides, OT/VP signaling system has also been reported in a number of other vertebrates such as birds, reptiles, amphibians and fishes, which all are supposed to have evolved from vasotocin, the ancestral nonapeptide, by gene duplication [18].

In invertebrates, OT or VP-like peptide has been widely identified among various phyla, while the co-occurrence of the two in the same species had never been demonstrated. In crustaceans, the OT/VP-like peptides have been reported in the blue swimming crab Portunus pelagicus, the water flea Daphnia pulex, the giant freshwater prawn Macrobrachium rosenbergii and the mud crab Scylla paramamosain, but lack of function tests [19-22]. Though the functional expression in cells and characterisation of OT/VP-like receptor have been investigated in mollusks, insects and nematodes, so far it isn't studied in crustaceans [20,23-25].

In oviparous animals, the vitellogenesis, divided into autosynthesis and heterosynthesis according to the yolk origins, is an important process for the formation and accumulation of various yolk substances, which can provide nutrients and energy for the development of embryos and early larvae [26]. In crustaceans, the regulation on the ovarian maturation involves many neuropeptides. In the classic Panouse experiment in 1944, the removal of eyestalk in the shrimp Palaemon serratus resulted in enlarged ovaries and precocious eggs, suggesting that the effect was due to the removal of vitellogenesis-inhibiting hormone (VIH). Then it was isolated from the eyestalk of the American lobster Homarus americanus firstly and demonstrated to inhibit vitellogenesis $[27,28]$. Recently, crustacean female sex hormone (CFSH), isolated from the sinus gland of the blue crab Callinectes sapidus, is considered to be the female sex-determining hormone [29]. Besides in S. paramamosain, the red-pigment concentrating hormone $(\mathrm{RPCH})$, secreted from the eyestalk ganglion, stimulates ovarian development, while the short neuropeptide F (sNPF) and allatostatin-C show inhibitory effect on ovarian development $[30,31]$. In P. pelagicus, it was reported that the P $p$ OT/VP-like peptide could inhibit the release of steroid hormones (17 $\beta$-estradiol and progesterone) in ovarian explants in vitro [19]. Up to now, the molecular mechanism of OT/VP-like peptides on crustacean reproduction is unclear.

In this study, Spot/op and Spot/opr-like gene sequences were cloned from S. paramamosain, the tissue distribution and expression profiles during vitellogenesis were detected. Moreover, in vivo and in vitro experiments were performed to explore the role of the signaling system in vitellogenesis.

\section{Results}

\subsection{Molecular Cloning and Bioinformatics of SpOT/VP-Like Preprohormone}

The full-length sequence of Spot/vp-like (GenBank accession: MT123288) cDNA is $853 \mathrm{bp}$ with $63 \mathrm{bp}$ $5^{\prime}$ untranslated region (UTR), $313 \mathrm{bp} \mathrm{3'} \mathrm{UTR} \mathrm{and} 477 \mathrm{bp}$ open reading frame (ORF). The preprohormone is composed of 158 amino acids containing a nonapeptide with the structure CFITNCPPGamide, which is located after a signal sequence and followed by a dibasic cleavage sites (GKR) and a neurophysin. The nonapeptide has a predicted molecular weight of $951.12 \mathrm{Da}$ and a theoretical isoelectric point of 5.51, and the neurophysin has 14 cysteine residues (Figure A1A). Multiple sequence alignment suggests that the nonapeptides and three rigid cage-like domains are highly conserved: a neuropeptide-containing domain (one disulfide bonds) and two neurophysin domains (one four and the other three disulfide bonds) (Figure 1). Phylogenetic analysis show that $S p O T / V P-l i k e$ preprohormone is clustered into the branch of crustaceans, then the branch with mollusks before insects (Figure A2).

\subsection{Molecular Cloning and Bioinformatics of SpOT/VPR-Like Preprohormone}

The Spot/vpr-like (GenBank accession: MT123289) cDNA ORF sequence is 1308 bp encoding 435 amino acids, which contains seven $\alpha$-helical transmembrane (TM) regions with a predicted molecular weight of 48,067.19 Da and a theoretical isoelectric point of 7.01. The N-terminal domain is in the 
extracellular with two sites of N-linked glycosylation (Asn-X-Ser/Thr) and the C-terminal is in the intracellular. The preprohormone also contains some consensus sequences sites about phosphorylation for protein kinase C (Ser/Thr-X-Arg/Lys), casein kinase II (Ser/Thr-X-X-Asp/Glu) and cAMP-dependent protein kinase (Arg/Lys-Arg/Lys-X-Ser/Thr) (Figure A3) [32]. Multiple sequence alignment suggests that, except TM regions, the first and second extracellular loops, between $\mathrm{TM}_{2}$ and $\mathrm{TM}_{3}$ and between $\mathrm{TM}_{4}$ and $\mathrm{TM}_{5}$ respectively, have the highest homology, while the third intracellular loop shows hardly any sequence identity, in which SpOT/VPR-like preprohormone contains $\sim 20$ amino acids more than vertebrate receptors (Figure 2).

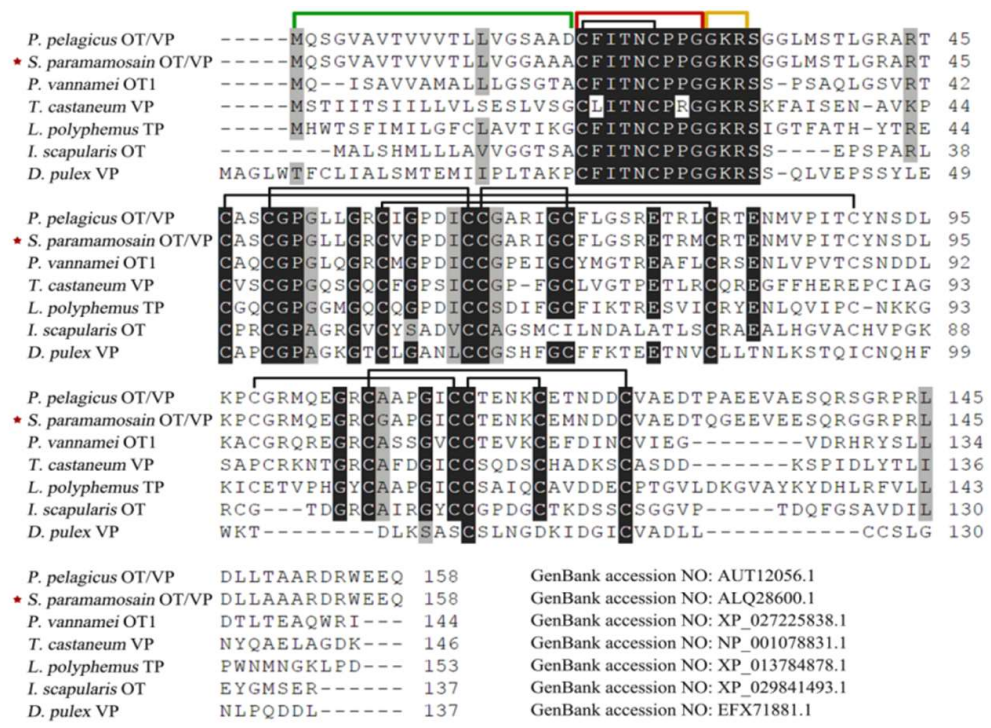

Figure 1. Multiple sequence alignment of deduced preprohormone sequences from SpOT/VP-like peptide and other OT/VPs. Numbers of amino acid are listed on the right side. Nonapeptides, cleavage sites and signal peptides are marked in red, yellow and green semi-frames respectively and disulfide bonds are shown on black. OT: oxytocin; VP: vasopressin.

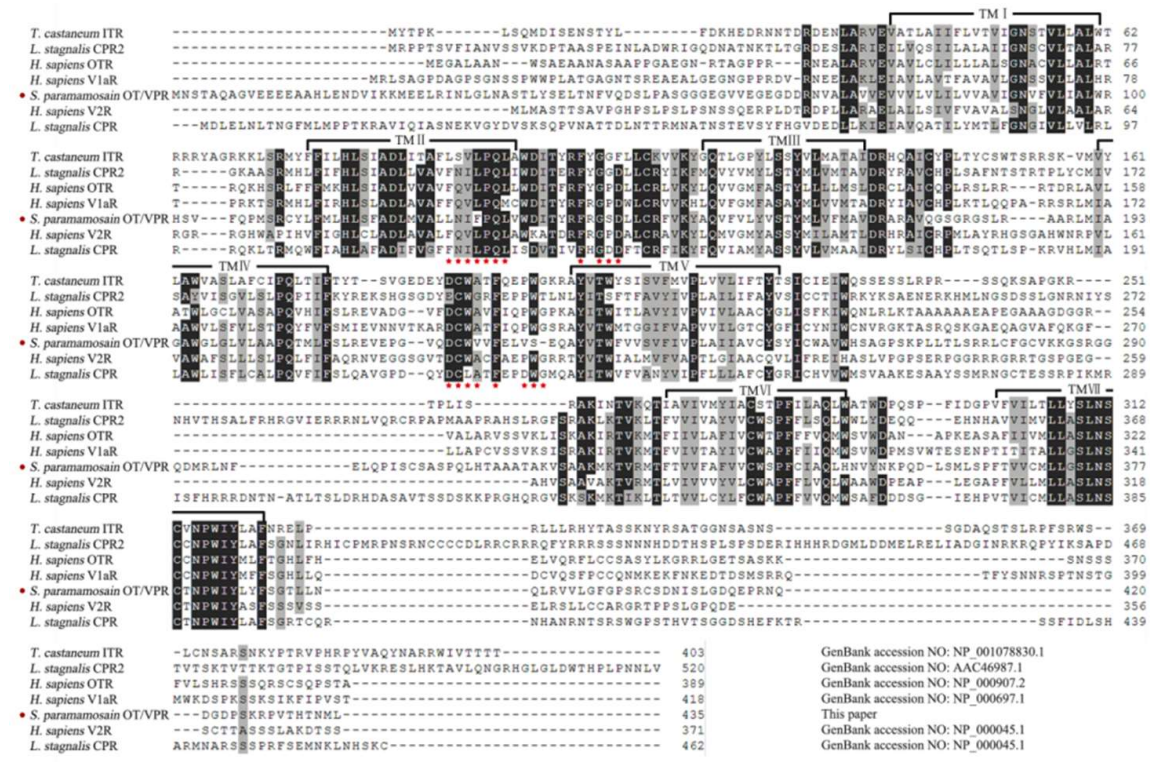

Figure 2. Multiple sequence alignment of deduced preprohormone sequences from SpOT/VP-like receptor and other OT/VPRs. Numbers of amino acid are listed on the right side. Seven transmembrane domains are shown on black semi-frames. 


\subsection{Expression Profiles of Spot/op and Spot/opr-Like mRNA}

RT-PCR shows that Spot/vp-like transcripts highly expressed in the nervous tissues, midgut, gill and epidermis, less express in the hepatopancreas and ovary, and hardly detected in the others. Spot/vpr-like are widespread in various tissues including the hepatopancreas, ovary and hemocytes (Figure 3A). qRT-PCR shows that there is a consistent temporal expression profile between Spot/vp-like transcripts in the nervous tissues and ovary and Spot/opr-like in the ovary: highest expression level at pre-vitellogenic stage, significantly down-regulated at early and maintained lower at late (Figure 3B,C).
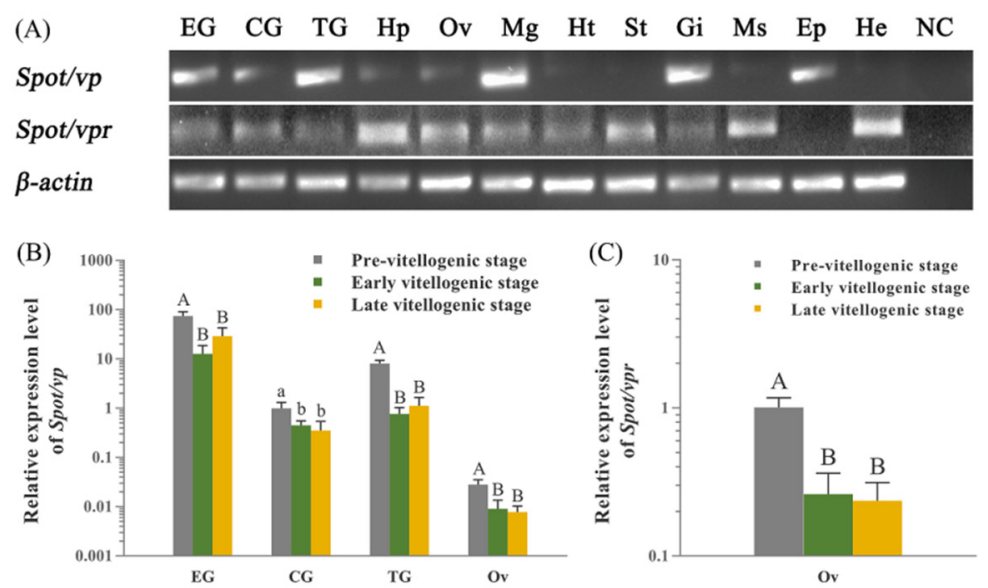

Figure 3. Expression analysis of Spot/vp and Spot/vpr-like transcripts in S. paramamosain. (A) Tissue distribution of Spot/vp and Spot/vpr-like transcripts in 12 tissues of early vitellogenic stage S. paramamosain: EG, eyestalk ganglion; CG, cerebral ganglion; TG, thoracic ganglion; Hp, hepatopancreas; Ov, ovary; $\mathrm{Mg}$, midgut; Ht, heart; St, stomach; Gi, gill; Ms, muscle; Ep, epidermis; He, hemocyte; NC, negative control (a PCR reaction performed without adding template). (B) Expression analysis of Spot/vp-like transcripts at different vitellogenic stages in EG, CG, TG and Ov. (C) Expression analysis of Spot/vpr-like transcripts at different vitellogenic stages in Ov. $\beta$-actin as the reference gene. ("a and b", $p<0.05$; “A and B", $p<0.01$; one-way ANOVA followed by Tukey' s multiple range tests; $n=5$ ).

\subsection{In Situ Hybridisation of Spot/op and Spot/opr-Like mRNA}

The Spot/vp-like mRNA is mainly detected in 6th, 7th clusters of protocerebrum and 8th, 9th of deutocerebrum, and both in the oocytes and follicular cells of ovary (Figure 4A-I). The Spot/vpr-like is mainly localised in the F-cells of hepatopancreas and the oocytes in the ovary (Figure 4J-O). All control sections, probed with sense strand RNA, show no positive signal.

\subsection{Synthetic SpOT/VP-Like Peptide Treatment In Vitro}

In the hepatopancreas cultured in vitro, the mRNA expression level of Spvg is significantly down-regulated at $12 \mathrm{~h}$ with $10^{-7} \mathrm{M}$ synthetic peptide administration $(p<0.05)$ (Figure 5A). The levels of $E_{2}$ in the media is significantly decreased at $6 \mathrm{~h}, 10^{-8} \mathrm{M}$ treatment and $12 \mathrm{~h}, 10^{-7}$ and $10^{-8} \mathrm{M}$ treatments, respectively $(p<0.05)$, and extremely significantly declined at $12 \mathrm{~h}, 10^{-6} \mathrm{M}$ treatment $(p<0.01)$ (Figure 5B). In the ovary, the mRNA expression level of Spvgr is extremely significantly down-regulated at $12 \mathrm{~h}, 10^{-9} \mathrm{M}$ treatment $(p<0.01)$ (Figure $\left.5 \mathrm{C}\right)$. The levels of $\mathrm{E}_{2}$ in the media is highly significantly lower at $6 \mathrm{~h}, 10^{-9} \mathrm{M}$ treatment $(p<0.01)$, and significantly declined at $12 \mathrm{~h}, 10^{-9} \mathrm{M}$ treatment, respectively $(p<0.05)$ (Figure 5D). 


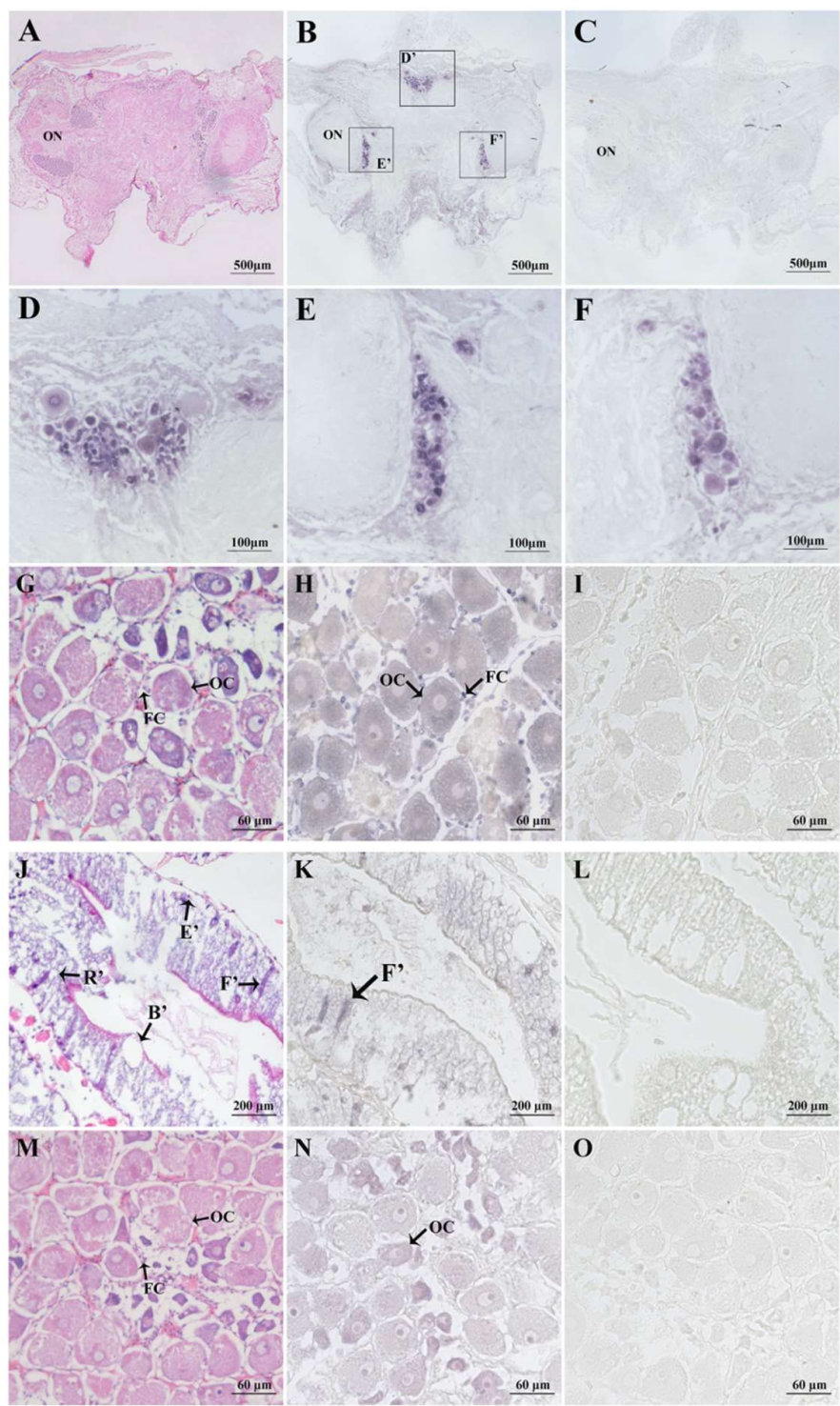

Figure 4. In situ hybridisation. (A-F) Spot/vp-like RNA of the cerebral ganglion. (A), Hematoxylin-eosin (H\&E) staining; (B), antisense probe; (C), sense probe; D), the cell cluster 6, 7; (E,F), the cell cluster 8, 9. ON, olfactory neuropile. (G-I) Spot/vp-like RNA of the ovary. (G), Hematoxylin-eosin (H\&E) staining; (H), antisense probe; (I), sense probe. OC, oocytes; FC, follicular cells. (J-L) Spot/vpr-like RNA of the hepatopancreas. (J), Hematoxylin-eosin (H\&E) staining; (K), antisense probe; $(\mathbf{L})$, sense probe. B', B-cell; F', F-cell; R', R-cell; E', E-cell. (M-O): Spot/vpr-like RNA of the ovary. (M), Hematoxylin-eosin (H\&E) staining; $(\mathbf{N})$, antisense probe; $(\mathbf{O})$, sense probe. 

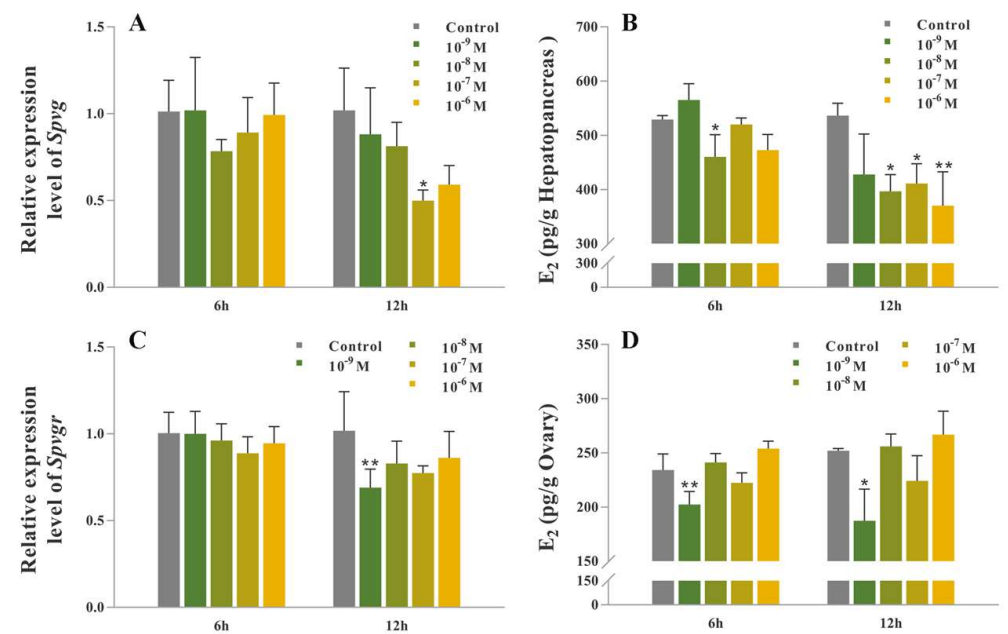

Figure 5. Effects of synthetic $S p \mathrm{OT} / \mathrm{VP}$-like peptide on gene expressions and $\mathrm{E}_{2}$ contents in vitro. (A) Relative expression level of Spvg in the hepatopancreas. (B) Release of $E_{2}$ from the hepatopancreas. (C) Relative expression level of Spvgr in the ovary. (D) Release of $\mathrm{E}_{2}$ from the ovary. $\beta$-actin as the reference gene. ${ }^{*} p<0.05$; ${ }^{* *} p<0.01$; one-way ANOVA followed by Dunnett's T tests; $\mathrm{n}=5$ ).

\subsection{Synthetic SpOT/VP-Like Peptide Treatment In Vivo}

The mRNA expression level of Spvg in the hepatopancreas and the $\mathrm{E}_{2}$ content in haemolymph are significantly down-regulated after the injection of synthetic peptide $(p<0.05)$ (Figure 6A,C). The mRNA expression levels of Spvg and Spvgr in the ovary were both not decreased significantly, but showed the inhibitory trends (Figure 6B). The oocyte diameter in the peptide injection group $(52.8 \pm 3.96 \mu \mathrm{m})$ was significantly shorter than that in crustacean physiological saline (CPS) group $(74.6 \pm 5.18 \mu \mathrm{m})$ (Figure 6D-G).
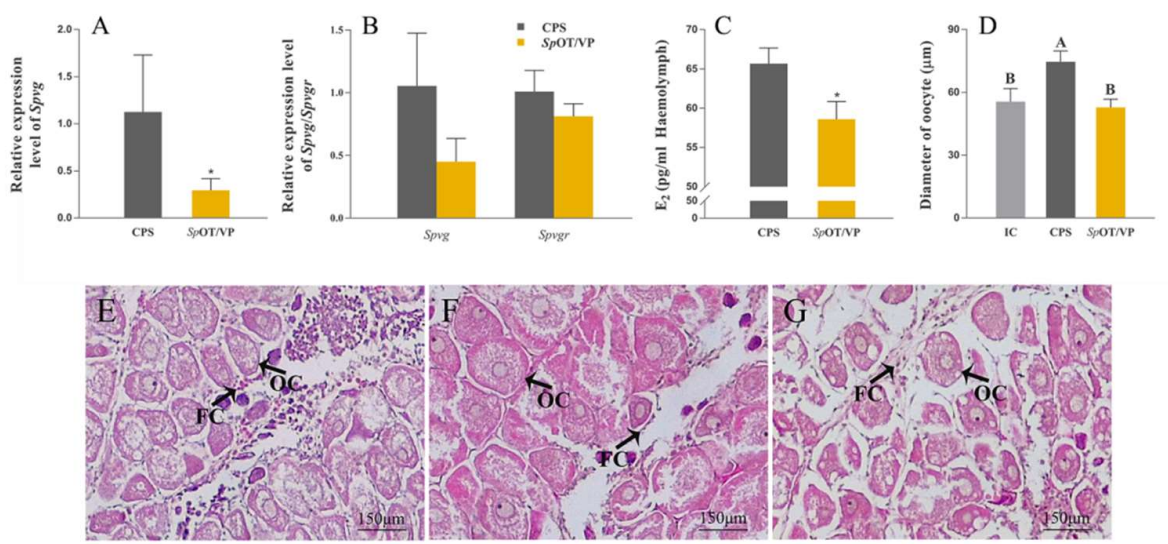

Figure 6. Effects of synthetic SpOT/VP-like peptide on gene expressions, $\mathrm{E}_{2}$ contents and ovarian development in vivo. (A) The relative expression level of Spvg in the hepatopancreas. (B) The relative expression level of Spvg and Spvgr in the ovary. (C) The content of $\mathrm{E}_{2}$ in the haemolymph. $\beta$-actin as the reference gene. (* $p<0.05 ;{ }^{* *} p<0.01$; one-way ANOVA followed by Dunnett' $\mathrm{s} \mathrm{T}$ tests; $\mathrm{n}=5$ ). (D-G) Histological changes of ovarian development. (D), diameter of oocytes; (E), initial control (IC); (F), negative control (CPS); (G), group injected with synthetic peptide. OC, oocytes; FC, follicular cells. ("a and b", $p<0.05$; "A and B", $p<0.01$; one-way ANOVA followed by Tukey' s multiple range tests; $n=5$ ).

\subsection{RNA Interference in the Hepatopancreas Explants In Vitro}

In the hepatopancreas explants, the mRNA expression level of Spot/vpr was significantly down-regulated after the RNA interference $(p<0.05)$ (Figure 7A); simultaneously, the mRNA 
expression level of Spvg was significantly up-regulated with the treatment of synthetic peptide after RNA interference $(p<0.05)$ (Figure 7B).
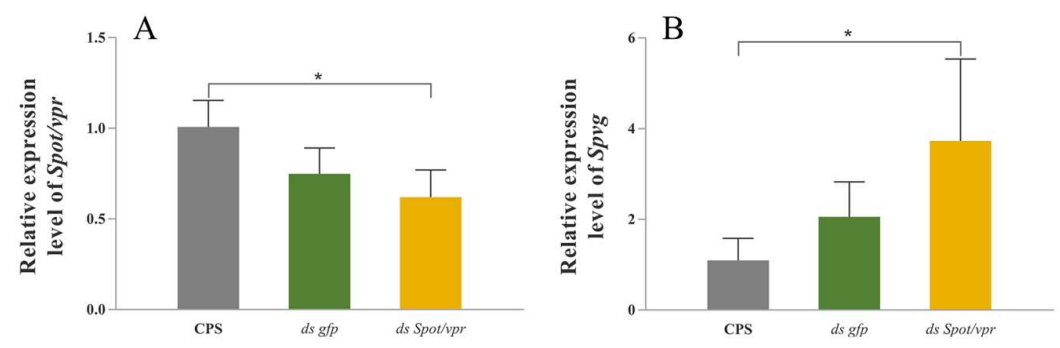

Figure 7. Effects of RNAi in the hepatopancreas explants in vitro. (A) Effects of RNAi with the application of Spot/vpr dsRNA. (B) Relative expression level of Spvg with the application of synthetic SpOT/VP-like peptide after RNAi. $\beta$-actin as the reference gene. ${ }^{*} p<0.05$; one-way ANOVA followed by Tukey' $\mathrm{s}$ T tests; $\mathrm{n}=5$ ).

\section{Discussion}

Hitherto, the study of OT/VP-like signaling system in crustacean reproduction has been rarely reported. In this study, it is suggested that the signaling system can inhibit vitellogenesis by means of neuroendocrine and autocrine/paracrine in S. paramamosain.

$S p \mathrm{OT} / \mathrm{VP}$-like precursor sequence is more than $60 \%$ similar to those of other crustaceans such as Portunus pelagicus (GenBank accession: AUT12056.1) and Penaeus vannamei (GenBank accession: ROT67110.1). The molecular structure of the nonapeptides is highly conserved in various phyla, which makes it more universal to induce the functional response resulted from heterogenous OT/VPs. The bioactivity, resulted from Conus arg-conopressin-g/s in the brain of rat, is similar to those induced by vertebrate OT/VPs [33]. And the OT-like peptide from the pufferfish Fugu rubripes can functionally express in rat nerve cells [34]. Therefore, the discovery and functional screening of natural OT/VP peptides is an effective strategy for ligand selection and drug discovery, targeting at human OT/VP receptors [35]. OT/VP-like precursors in crustaceans clustered with those in mollusks firstly, then insects which belong to the same clade Pancrustacea. The strange result may be because that crustaceans are more closely related to the common ancestor of arthropods than insects in evolutionary status, such as D. pulex, considered to be the ancestor of insects with the divergence in $\sim 420$ million years ago [36]. Moreover, in order to adapt to a variety of environments during the evolution process from aquatic to terrestrial taxa, structures and functions of arthropods evolve over time. The OT/VP signaling system, lasting to crustaceans, is lost at least twice in insects which had been replaced by AKH, CCAP or Corazonin hormone systems, all participating in osmotic regulation and metabolism etc. [20].

The SpOT/VPR-like is a G-protein coupled receptor with seven $\alpha$-helical transmembrane regions. Except TMs regions, the first and second extracellular loops are the most conserved regions, connected by a disulfide bonds and important in ligand binding [37]. The sites of $\mathrm{N}$-linked glycosylation in the extracellular N-terminal domain contribute to the target to plasma membrane, and the consensus sequences sites about phosphorylation are important in the modulation of $G$ protein coupling and receptor function [32]. Compared with OT, SpOT/VPR-like sequence is more similar to $\mathrm{V}_{1 \mathrm{a}} \mathrm{R}$ in mammals such as the mouse Mus musculus (GenBank accession: NP_058543.2) and the domestic horse Equus caballus (GenBank accession: XP_001917958.4) with homologies over 40\%, suggesting that it may be a VP-like receptor. And when synthetic SpOT/VP was added after knocking down Spot/vpr in vitro, the inhibitory effect of synthetic peptide was relieved, indicating that the receptor was SpOT/VPR-like to some extent. It is the first time to clone and characterise OT/VPR-like in crustaceans. There are usually two sets of OT/VP signaling systems in molluscs, probably due to the additional gene replication $[9,25]$. Similarly, two OT/VP-like receptor (GenBank accession: ROT66533.1; XP_027226674.1) sequences, found in the genomic database of $P$. vannamei, suggested that multiple OT/VP signaling systems may also exist in crustaceans. 
Spot/vp-like mRNA transcripts are mainly expressed in the nervous system, which is similar to the immunohistochemical results of invertebrates such as the hydrozoan Hydra magnipapillata and the polychaete Neanthes japonica, and the in situ hybridisation outcomes in the ant Camponotus fellah and the octopuses Octopus vulgaris [38-42]. The transcripts are also highly expressed in the midgut and gill, having the same expression pattern to Ppot/vp-like mRNA transcripts in P. pelagicus [19]. It is suggested that $S p O T / V P-l i k e$ peptide can be involved in osmotic regulation, which is probably induced via crustacean hyperglycaemic hormone $(\mathrm{CHH})$ as reported in the crab Pachygrapsus marmoratus and the crayfish Astacus leptodactylus [43,44]. Spot/opr-like mRNA transcripts are expressed in various tissues, suggesting that SpOT/VP signaling system is pleiotropic, similar to Lys-CP (from Lymnaea stagnalis) and OP (from Octopus vulgaris) [24,25,42].

In situ hybridisation shows that Spot/vp-like mRNA, similar to mollusk op/ct, is distributed in various kinds of neurons in cerebral ganglion, such as 6th and 7th neuronal clusters involved in reproductive regulation, and 8th and 9th in olfaction, learning and memory regulation [45-47]. Spot/opr-like mRNA is expressed in F-cells of hepatopancreas, the main sites of enzyme synthesis, suggesting that the system may participate in the regulation of hepatopancreas on digestion, metabolism and reproduction. Besides, at early vitellogenic stage, Spot/vp-like mRNA distributes in oocytes/follicular cells, while Spot/vpr-like distributes in oocytes, indicating that SpOT/VP-like from oocytes/follicular cells might act on oocytes. This result is different from the short neuropeptide $\mathrm{F}$ (sNPF) previously reported in the ovary in S. paramamosain, which showed that SNPF, synthesised by follicular cells, could act on oocytes/follicular cells [48]. Therefore, the communication might exist between oocytes and follicular cells in S. paramamosain, and we speculated that regulatory mode of autocrine/paracrine factors in the ovary is multifarious in crustaceans.

In mammals, both stimulatory and inhibitory effects of OT/VP/VTs on the release of $E_{2} / \mathrm{P}_{4}$ (Progesterone), the vertebrate-type steroid hormones, from granulosa cells were reported [49-51]. Besides, in the catfish Heteropneustes fossilis, the vasotocin detected in granulosa cells of post-vitellogenic and absent in immature follicles, could promote the releases of $\mathrm{E}_{2}, \mathrm{P}_{4}, \mathrm{P}_{4}$ derivatives and prostaglandin, and cause the germinal vesicle breakdown and ovulation, which was suggested to correlate with the stage of luteinisation [52-55]. The $\mathrm{E}_{2}$ and $\mathrm{P}_{4}$-like were first discovered in crustaceans in 1978 [56]. Furthermore, the existence of $\mathrm{E}_{2} / \mathrm{P}_{4}$ in hepatopancreas, ovary and haemolymph, and the presence and activities of steroid-related enzymes (20 $\alpha$-HSD, 17 $\beta$-HSD, 3 $\beta$-HSD, 17 $\beta$-HSD8) were recently reported in crustaceans, by which vitellogenesis was controlled [57-62]. Temporal expression profiles of Spot/vp and Spot/vpr-like mRNA showed that they might be involved in inhibiting ovarian development. Both in vitro cultured and in vivo long-term injection experiment showed that synthetic SpOT/VP-like peptide could significantly inhibit the expression of Spvg/Spvgr in the hepatopancreas/ovary, respectively, which could be achieved by inhibiting the release of $17 \beta$-estradiol $\left(E_{2}\right)$ from the hepatopancreas/ovary. Histological analysis further showed that ovarian development was suppressed after the injection of synthetic peptide, with the significantly subduced oocyte growth. And it is probably resulted from less synthesis of yolk substances, and lack of accumulation of yolk substances in oocytes. Similarly, in $P$. pelagicus, the synthetic $P p \mathrm{OT} / \mathrm{VP}$-like peptide also significantly inhibited the releases of $\mathrm{E}_{2}$ and $\mathrm{P}_{4}$ in the culture media from stage II and IV ovaries [19]. In conclusion, SpOT/VP-like signaling system might inhibit vitellogenesis as neuroendocrine and autocrine/paracrine factors by inhibiting the release of $E_{2}$ in S. paramamosain. This paper has enriched the researches on the OT/VP signaling system and the effect of neuropeptides on reproductive regulation in crustaceans. However, the detailed mechanisms on ovarian development should be clarified with more experiments in the future.

\section{Materials and Methods}

\subsection{Animals}

The female S. paramamosain, purchased at No.8 fishery market, Xiamen, China, were kept in plastic tanks containing sea water with aeration for $6 \mathrm{~h}$ at $27.0 \pm 2.0^{\circ} \mathrm{C}$ (temperature) and $27.0 \pm 0.5 \mathrm{ppm}$ 
(salinity), and fed with fresh clam Ruditapes philippinarum. In S. paramamosain, vitellogenesis can be classified into three stages according to the previous study: pre-vitellogenic, early vitellogenic and late vitellogenic stage [63]. All animal procedures were carried out in strict compliance with the National Institute of Health Guidelines for the Care and Use of Laboratory Animals.

\subsection{Molecular Cloning, Bioinformatics and Phylogenetics of SpOT/VP-Like Peptide and Its Receptor}

Search for the nucleotide sequences of Spot/vp-like peptide and its receptor in the transcriptome of $S$. paramamosain cerebral ganglia, reported in previous studies, by BLAST against GenBank, non-redundant (Nr) and Gene Ontology (GO) [22]. The RNA, extracted from cerebral ganglia using Trizol reagent (Invitrogen, Carlsbad, CA, USA), was used for cDNA synthesis with the RevertAid ${ }^{\mathrm{TM}}$ First Strand cDNA Synthesis Kit (Fermentas Inc., Ontario, Canada) and 5'/3' RACE-cDNA synthesis with the SMART ${ }^{\mathrm{TM}}$ RACE cDNA Amplification Kit (TaKaRa, Shiga, Japan). The full sequence was cloned according to the user manual for the SMART TM RACE $5^{\prime} / 3^{\prime}$ Kit. All PCR products, separated by $1.0 \%(w / v)$ agarose gel electrophoresis and purified using agarose gel purification and extraction kit (Aidlab, Beijing, China), were cloned into the pMD19-T vector (Promega, Madison, WI, USA) and sequenced by Sangon Biotechnology Company Limited (Shanghai, China). ORFs and amino acid sequences were predicted by DNAStar software, and protein composition, molecular weight and isoelectric point were analysed by ExPASy software. The preprohormone sequences of OT/VPs and OT/VPRs from S. paramamosain against other species were obtained from NCBI, which were used to create the multiple sequence alignment by MEGA 7.0 software. Phylogenetic trees were carried out via the neighbor-joining method with 1000 bootstrap replicates using MEGA 7.0 software. Moreover, signal peptides were predicted by SignalP 5.0, cleavage sites, post-translational modifications and bioactive peptide products were predicted by NeuroPred, and transmembrane domains were predicted by TMHMM tool. All primers are listed in Table A1.

\subsection{Tissue Distributions of Spot/op and Spot/opr-Like mRNA}

The RNAs $(n=3)$, extracted from eyestalk ganglion, cerebral ganglion, thoracic ganglion, hepatopancreas, ovary, midgut, heart, stomach, gill, muscle, epicdermis and hemocytes at early vitellogenesis stage, were used for cDNA synthesis. Semi-quantitative RT-PCR was performed to detect the tissues distributions of Spot/vp and Spot/vpr-like transcripts. The reaction system was a volume of $25.0 \mu \mathrm{L}$ containing $12.5 \mu \mathrm{L} 2 \times$ Premix Ex TaqII (Takara, Shiga, Japan), $1.0 \mu \mathrm{L}$ cDNA, 0.5 $\mu \mathrm{M}$ each primer $(10 \mu \mathrm{M})$ and $10.5 \mu \mathrm{L} \mathrm{H}_{2} \mathrm{O}$. The thermocycling parameters were one cycle at $94^{\circ} \mathrm{C}$ for $3 \mathrm{~min}, 35$ cycles at $94{ }^{\circ} \mathrm{C}$ for $30 \mathrm{~s}, 57^{\circ} \mathrm{C}$ for $30 \mathrm{~s}$ and $72{ }^{\circ} \mathrm{C}$ for $30 \mathrm{~s}$, and a final extension at $72{ }^{\circ} \mathrm{C}$ for $10 \mathrm{~min}$. The specificity control was performed using water as template and the internal control was performed using $\beta$-actin. All PCR products were separated by $1.5 \%(w / v)$ agarose gel electrophoresis with $1 \times$ TAE Buffer (Solarbio, Beijing, China) and observed and photographed by gel imaging and analysis system (Bio-Rad, Shanghai, China). Three technical replicates were performed.

\subsection{In Situ Hybridisation of Spot/op and Spot/opr-Like mRNA}

The fragments of Spot/vp (310bp) and Spot/vpr-like (288bp) sequences were cloned into pGEM-T easy vector (Promega, Madison, WI, USA). The linear DNAs, amplified by PCR, were used as templates for riboprobes construction using DIG-Oligonucleotide Labeling Kit (Roche Molecular Biochemicals, Mannheim, Germany). Cerebral ganglia, hepatopancreas and ovaries at early vitellogenic stage were dissected and prepared for the paraffin-cut section. The serial seven-micron sections were used for Hematoxylin-eosin (H\&E) staining and in situ hybridisation [64], visualised by the BCIP/NBT Chromogen Kit (Solarbio, Beijing, China) and mounted in Clear-Mount. All sections were observed and photographed by fluorescence confocal microscope (version, Axio Imager A2) equipped with digital camera (version, AxioCam MRc) (Carl Zeiss, Jena, Germany). Three technical replicates were performed. 


\subsection{Temporal Expression Profiles of Spot/op and Spot/opr-Like mRNA}

The RNAs, extracted from nervous tissues and ovary at three vitellogenic stages ( $n=5$ per stage), were used for cDNA synthesis. Quantitative real-time PCR (qRT-PCR) was performed by a QuantStudio $^{\mathrm{TM}} 6$ Flex Real-Time PCR (Applied Biosystems) with SYBR ${ }^{\circledR}$ Select Master Mix (TaKaRa, Shiga, Japan) according to the user manual. The internal control was performed using $\beta$-actin.

\subsection{Synthetic SpOT/VP-Like Peptide Treatment In Vitro}

The SpOT/VP-like peptide (CFITNCPPG-NH2) used in this study was commercially synthesised by GL Biotechnology Company Limited (Shanghai, China). The crabs at early vitellogenic stage $(n=5)$ were anesthetised on ice for $10 \mathrm{~min}$ and sterilised in $75 \%$ ethanol for $10 \mathrm{~min}$. Fragments of hepatopancreas and ovaries $(\sim 0.2 \mathrm{~g})$ were dissected out, washed in CPS, and precultured at $26{ }^{\circ} \mathrm{C}$ in 24-wells plates with $200 \mu \mathrm{L}$ Leibovitz's L-15 medium (Gibco Invitrogen Corporation, Grand Island, NY, USA) each well. One hour later, substituted the medium with L-15 medium containing different concentration of synthetic peptide $\left(0,10^{-9}, 10^{-8}, 10^{-7}\right.$ and $\left.10^{-6} \mathrm{M}\right)$ and incubated for 6 or $12 \mathrm{~h}$. Then, collected the fragments for RNA extraction and cDNA synthesis. $\beta$-actin was used as the internal control, and qRT-PCR was performed to detect the relative transcript levels of Spvg and Spvgr. Meanwhile, culture media were collected and handled according to the steroid extraction protocol, and the level of $E_{2}$ in the media were measured by Detect $X^{\circledR}$ SERUM $17 \beta$-ESTRADIOL Enzyme Immunoassay Kit (Arbor Assays, Ann Arbor, MI, USA). Three technical replicates were performed.

\subsection{Synthetic SpOT/VP-Like Peptide Injection}

The crabs at early vitellogenic stage were randomly divided into two groups ( $n=5$ per group), injected with $100 \mathrm{ng} / \mathrm{g}$ synthetic peptide or CPS, with the same volume, respectively. In addition, $5 \mathrm{crab}$ without treatment were as initial control. Injections were given every four days for a total of 17 days duration, and on the 18th day, hepatopancreas and ovaries were collected and treated, and haemolymph was extracted and measured as above. Besides, the ovary tissues were dissected and prepared for the paraffin-cut section. The serial seven-micron sections were performed using H\&E staining and the diameter of oocytes were measured. Three technical replicates were performed.

\subsection{RNA Interference In Vitro}

The fragments of Spot/vpr-like ( $478 \mathrm{bp}$ ) and $g f p(454 \mathrm{bp})$ sequences were cloned into the pGEM-T easy vector. The linear DNAs, amplified by PCR, were used as templates for $d s R N A$ transcribed by T7/SP6 polymerases. Hepatopancreas tissue was dissected out and treated as Section 2.7 with $200 \mu \mathrm{L}$ L-15 media containing $5 \mu \mathrm{g}$ Spot/vpr dsRNA or gfp dsRNA, and CPS with the same volume, respectively. After incubation at $26^{\circ} \mathrm{C}$ for $10 \mathrm{~h}$, substituted the media with $200 \mu \mathrm{L} \mathrm{L}-15$ media containing $10^{-8} \mathrm{M}$ synthetic peptide each well for $12 \mathrm{~h}$. The hepatopancreas explants were collected for RNA extraction and cDNA synthesis. $\beta$-actin was used as internal control, and qRT-PCR was performed to detect the relative expression levels of Spot/vpr and Spvg. Three technical replicates were performed.

\subsection{Statistical Analysis}

The relative expression levels were calculated via the $2^{-\Delta \Delta C t}$ algorithm. All data were expressed as mean \pm SD and analysed using One-way ANOVA followed by Tukey's multiple range tests, Dunnett' $\mathrm{s} T$ tests and Student's T-tests (SPSS Statistics 18.0) to estimate the statistical differences of mean levels among the groups with statistically significant at $p<0.05$ and extremely significant at $p<0.01$.

Author Contributions: D.L. designed and performed experiments, collected, analysed, discussed and interpreted data, prepared figures, wrote and edited the manuscript. Y.W. performed experiments, collected and analysed data. H.Y. contributed to experiment design, data discussion, reviewed and edited the manuscript. All authors have read and agreed to the published version of the manuscript.

Funding: This research was funded by the Natural Science Foundation of China (No. 31972765; 31772827). 
Acknowledgments: We thank all laboratory members for their constructive suggestions and discussions.

Conflicts of Interest: The authors declare no conflict of interest. The funders had no role in the design of the study; in the collection, analyses, or interpretation of data; in the writing of the manuscript, or in the decision to publish the results.

\section{Appendix A}

Table A1. Summary of primers used in this study.

\begin{tabular}{|c|c|c|}
\hline Primer & Sequence $\left(5^{\prime}-3^{\prime}\right)$ & Application \\
\hline OT/VP-F & CCGCCTGCTTTATTACCAACT & Fragment validation \\
\hline OT/VP-R & CCACGCAATCGTCATTCATTT & \\
\hline OT/VPR-F1 & GGTGGTGGAAGTGGTGGTGC & \\
\hline OT/VPR-R1 & TACTTGACAAAGCGGCAGAGGA & \\
\hline OT/VPR-F2 & TTCGTGGTGTCCGTGTTCAT & \\
\hline OT/VPR-R2 & GGAGAGTGCCGCTGAAGTAA & \\
\hline OT/VPR-F3 & TGCTCGGGTCCCTAAACAGT & \\
\hline OT/VPR-R3 & TTGAATGTAGTGTTGTGGCGTAG & \\
\hline OT/VP-3'-1 & GCGAGGAGGTGGAAGAAAGC & $3^{\prime} \mathrm{RACE}$ \\
\hline OT/VP-3'-2 & TCGTTGGGAGGAGCAGTGAG & \\
\hline OT/VP-5'-1 & GCACACCACGAAGGCGAACACTACC & $5^{\prime} \mathrm{RACE}$ \\
\hline $\mathrm{OT} / \mathrm{VP}-5^{\prime}-2$ & CTGAGCGTGAGGAGGGGCTTGGA & \\
\hline OT/VP-GF & CAGTCAACAGCAGCAGGCA & cDNA/gDNA validation \\
\hline OT/VP-GR & АСТТССАТТТССТТТАССАТТТСТА & \\
\hline OT/VPR-OF & GTGAGCGAGGGACCAAGAGG & ORF validation \\
\hline OT/VPR-OR & TGTAGTGTTGTGGCGTAGGAATGTTT & \\
\hline OT/VP-QF & AATCGGTTGCTTCCTTGGG & RT-PCR/qRT-PCR \\
\hline OT/VP-QR & ССТTССТGСАTССТАССАСА & \\
\hline OT/VPR-QF & GTGAGCGAGGGACCAAGAGG & \\
\hline OT/VPR-QR & GGAGGCGTTCAGACCCAAGT & \\
\hline Vg-QF & CGCAACCGCCACTGAAGAT & \\
\hline Vg-QR & CCACCATGCTGCTCACGACT & \\
\hline VgR-QF & TTCTATACCAGGCCACTACC & \\
\hline VgR-QRR & TTTTCACTCCAAGCACACTC & \\
\hline OT/VP-IF & AGTCAACAGCAGCAGGCAT & ISH \\
\hline OT/VP-IR & CAGGGTTTGAGGTCTGAGTTG & \\
\hline OT/VPR-IF & TGCTCGGGTCCCTAAACAGT & \\
\hline OT/VPR-IR & TTGAATGTAGTGTTGTGGCGTAG & \\
\hline OT/VPR-SF & CAGGCTTACGTCACCTGGTT & $d s R N A$ \\
\hline OT/VPR-SR & GAGTGCCGCTGAAGTAAAGG & \\
\hline
\end{tabular}




\section{Appendix B}

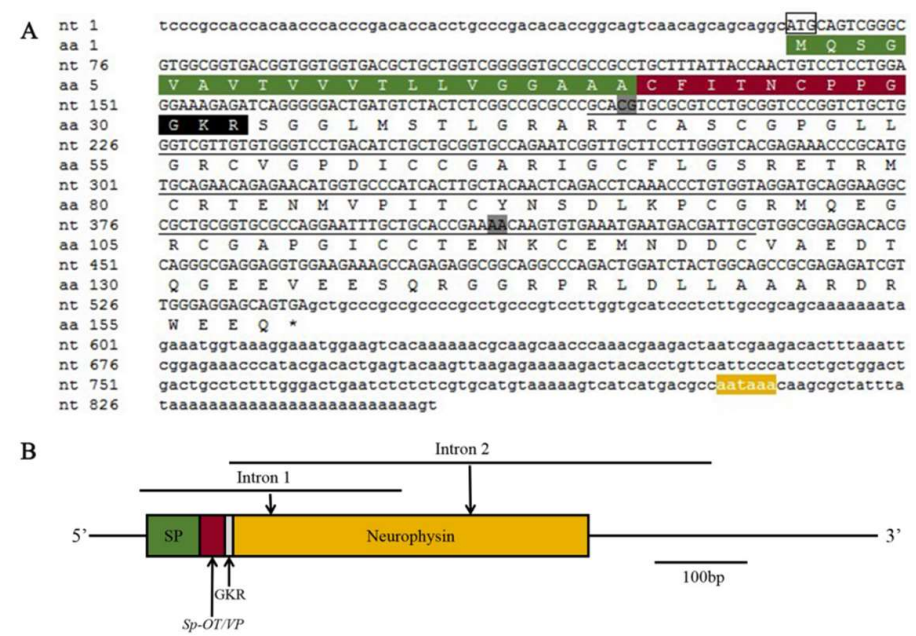

Figure A1. Nucleic acid and deduced preprohormone sequences of SpOT/VP-like peptide. (A) The start of ORF (ATG) is marked in box and the stop codon (TGA) is marked with * The signal peptide (SP) is shown on a green background and the nonapeptide is shown on a red. The cleavage site (GKR) is marked with a black background and the polyadenylation signal is marked with a yellow. The NH domain is underlined in black and the positions where introns are inserted are shown on gray backgrounds. (B) Spot/op cDNA is represented by the line between $5^{\prime}$ and $3^{\prime}$. The ORF is shown as boxes. The down arrows indicate the positions where introns are inserted and the lines above represent the length of each intron.

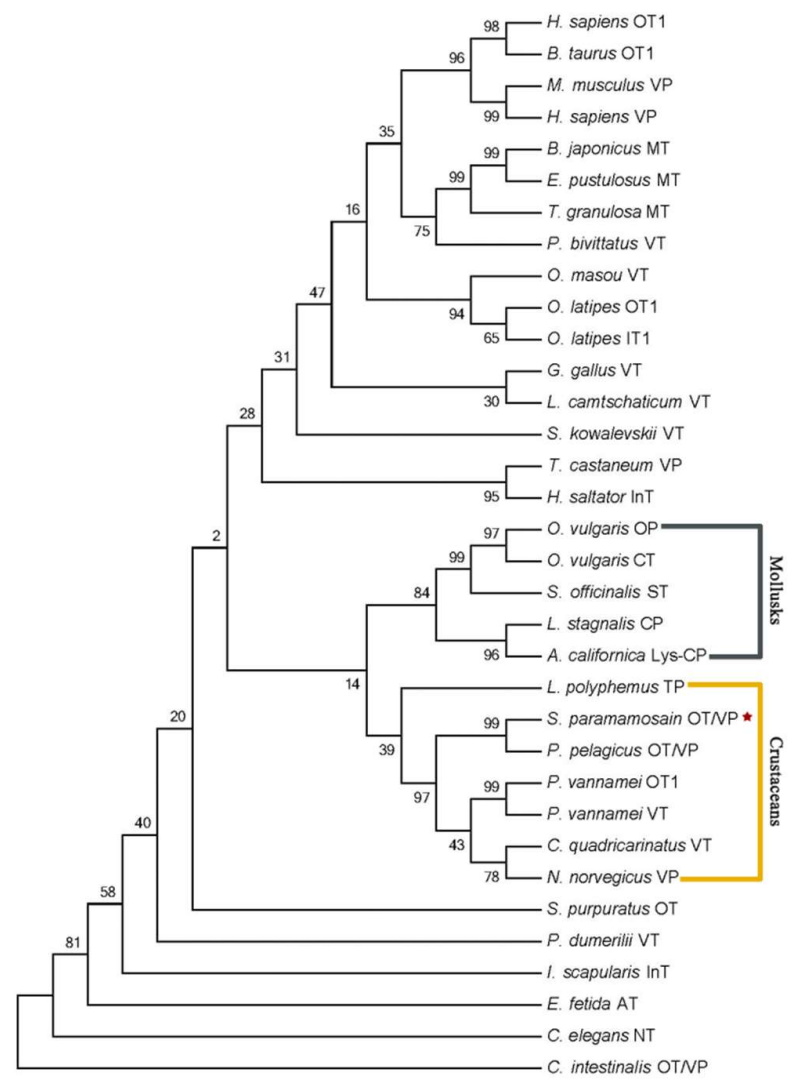

Figure A2. Phylogenetic analysis of deduced preprohormone sequences of OT/VPs. Phylogenetic trees were carried out via the neighbor-joining method with 1000 bootstrap replicates using MEGA 7.0 software. Shown at nodes are the N-J values. 


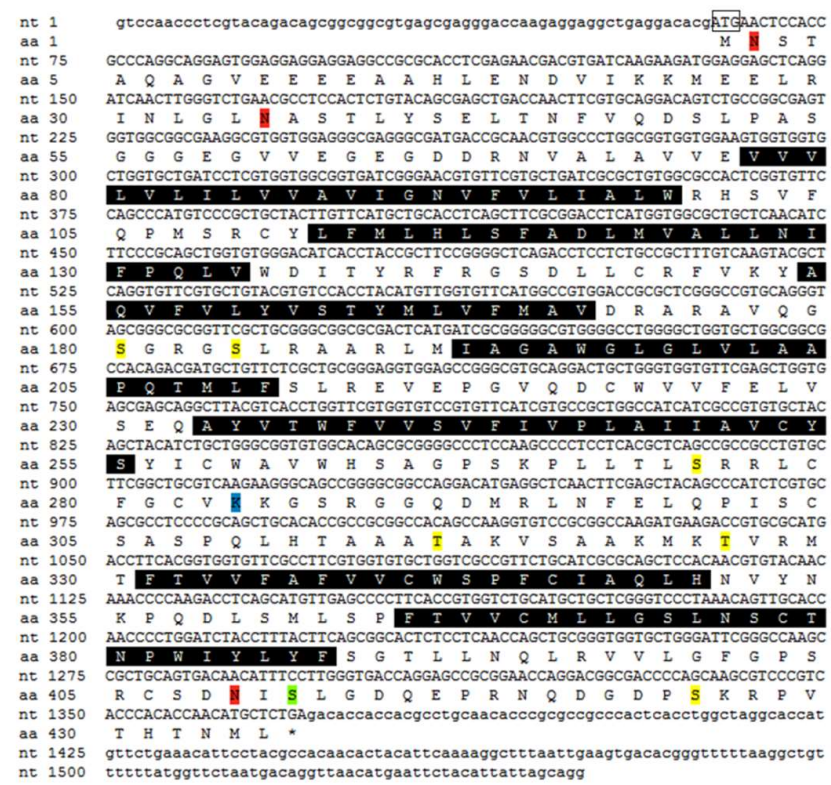

Figure A3. Nucleic acid and deduced preprohormone sequences of SpOT/VP-like receptor. The start of ORF (ATG) is marked in box and the stop codon (TGA) is marked with * Seven transmembrane domains are shown on black backgrounds. The predicted sites for N-linked glycosylation (Asn-X-Ser/Thr) are indicated by red backgrounds. The predicted sites for phosphorylation by protein kinase $C$ (Ser/Thr-X-Arg/Lys), casein kinase II (Ser/Thr-X-X-Asp/Glu) and cAMP-dependent protein kinase (Arg/Lys-Arg/Lys-X-Ser/Thr) are indicated by yellow, green and blue backgrounds, respectively.

\section{References}

1. Wathes, D.C. Possible actions of gonadal oxytocin and vasopressin. J. Reprod. Fertil. 1984, 71, 315-345. [CrossRef]

2. Vigneaud, V.D.; Ressler, C.; Trippett, S. The sequence of amino acids in oxytocin, with a proposal for the structure of oxytocin. J. Biol. Chem. 1953, 205, 949-957.

3. Vigneaud, V.D.; Lawler, H.C.; Popenoe, E.A. Enzymatic cleavage of glycinamide from vasopressin and a proposed structure for this pressor-antidiuretic hormone of the posterior pituitary. J. Am. Chem. Soc. 1953, 75, 4880-4881. [CrossRef]

4. Ivell, R.; Schmale, H.; Richter, D. Vasopressin and oxytocin precursors as model preprohormones. Neuroendocrinology 1983, 37, 235-240. [CrossRef] [PubMed]

5. Caldwell, H.K.; Young, W.S. Oxytocin and vasopressin: Genetics and behavioral implications. In Handbook of Neurochemistry and Molecular Neurobiology; Springer: Berlin, Germany, 2006; pp. 573-607.

6. Acher, R.; Chauvet, J.; Chauvet, M.T. Man and the chimaera: Selective versus neutral oxytocin evolution. Adv. Exp. Med. Biol. 1995, 395, 615-627. [PubMed]

7. De Bree, F.M.; Van Der Kleij, A.A.; Nijenhuis, M.; Zalm, R.; Murphy, D.; Burbach, J.P. The hormone domain of the vasopressin prohormone is required for the correct prohormone trafficking through the secretory pathway. J. Neuroendocrinol. 2003, 15, 1156-1163. [CrossRef]

8. MacDonald, K.; MacDonald, T.M. The peptide that binds: A systematic review of oxytocin and its prosocial effects in humans. Harv. Rev. Psychiatry 2010, 18, 1-21. [CrossRef]

9. Donaldson, Z.R.; Young, L.J. Oxytocin, vasopressin, and the neurogenetics of sociality. Science 2008, 322, 900-904. [CrossRef]

10. Buhimschi, C.S. Endocrinology of lactation. Obstet. Gynecol. Clin. N. Am. 2004, 31, 963-979. [CrossRef]

11. Ratajczak, C.K.; Muglia, L.J. Insights into parturition biology from genetically altered mice. Pediatr. Res. 2008, 64, 581-589. [CrossRef] [PubMed]

12. Banerjee, P.; Joy, K.P.; Chaube, R. Structural and functional diversity of nonapeptide hormone from an evolutionary perspective: A review. Gen. Comp. Endocrinol. 2017, 241, 4-23. [CrossRef] [PubMed] 
13. Jard, S.; Barberis, C.; Audigier, S.; Tribollet, E. Neurohypophyseal hormone receptor systems in brain and periphery. Prog. Brain Res. 1987, 72, 173-187. [PubMed]

14. Thibonnier, M.; Auzan, C.; Madhun, Z.; Wilkins, P.; Berti-Mattera, L.; Clauser, E. Molecular cloning, sequencing, and functional expression of a cDNA encoding the human V1a vasopressin receptor. J. Biol. Chem. 1994, 269, 3304-3310.

15. Sugimoto, T.; Saito, M.; Mochizuki, S.; Watanabe, Y.; Hashimoto, S.; Kawashima, H. Molecular cloning and functional expression of a cDNA encoding the human V1b vasopressin receptor. J. Biol. Chem. 1994, 269, 27088-27092.

16. Kimura, T.; Tanizawa, O.; Mori, K.; Brownstein, M.J.; Okayama, H. Structure and expression of a human oxytocin receptor. Nature 1992, 356, 526-529. [CrossRef]

17. Lolait, S.J.; O' Carroll, A.M.; McBride, O.W.; Konig, M.; Morel, A.; Brownstein, M.J. Cloning and characterization of a vasopressin V2 receptor and possible link to nephrogenic diabetes insipidus. Nature 1992, 357, 336-339. [CrossRef]

18. Stewart, M.J.; Harding, B.I.; Adamson, K.J.; Wang, T.; Storey, K.B.; Cummins, S.F. Characterisation of two conopressin precursor isoforms in the land snail, Theba pisana. Peptides 2015, 80, 32-39. [CrossRef]

19. Saetan, J.; Kruangkum, T.; Phanthong, P.; Tipbunjong, C.; Udomuksorn, W.; Sobhon, P.; Sretarugsa, P. Molecular cloning and distribution of oxytocin/vasopressin-like mRNA in the blue swimming crab, Portunus pelagicus, and its inhibitory effect on ovarian steroid release. Comp. Biochem. Physiol. A Mol. Integr. Physiol. 2018, 218, 46-55. [CrossRef]

20. Stafflinger, E.; Hansen, K.K.; Hauser, F.; Schneider, M.; Cazzamali, G.; Williamson, M.; Grimmelikhuijzen, C.J.P. Cloning and identification of an oxytocin/vasopressin-like receptor and its ligand from insects. Proc. Natl. Acad. Sci. USA 2008, 105, 3262-3267. [CrossRef]

21. Suwansa-Ard, S.; Thongbuakaew, T.; Wang, T.F.; Zhao, M.; Elizur, A.; Hanna, P.J.; Sretarugsa, P.; Cummins, S.F.; Sobhon, P. In silico neuropeptidome of female Macrobrachium rosenbergii based on transcriptome and peptide mining of eyestalk, central nervous system and ovary. PLoS ONE 2015, 10, e0123848. [CrossRef] [PubMed]

22. Bao, C.C.; Yang, Y.N.; Huang, H.Y.; Ye, H.H. Neuropeptides in the cerebral ganglia of the mud crab, Scylla paramamosain: Transcriptomic analysis and expression profiles during vitellogenesis. Sci. Rep. 2015, 5, 17055. [CrossRef] [PubMed]

23. Garrison, J.L.; Macosko, E.Z.; Bernstein, S.; Pokala, N.; Albrecht, D.; Bargmann, C.I. Oxytocin/vasopressin-related peptides have an ancient role in reproductive behavior. Science 2012, 338, 540-543. [CrossRef] [PubMed]

24. Van Kesteren, R.E.; Tensen, C.P.; Smit, A.B.; van Minnen, J.; van Soest, P.F.; Kits, K.S.; Meyerhof, W.; Richter, D.; van Heerikhuizen, H.; Vreugdenhil, E. A novel G protein-coupled receptor mediating both vasopressin- and oxytocin-like functions of Lys-conopressin in Lymnaea stagnalis. Neuron 1995, 15, 897-908. [CrossRef]

25. Van Kesteren, R.E.; Tensen, C.P.; Smit, A.B.; van Minnen, J.; Kolakowski, L.F.; Meyerhof, W.; Richter, D.; van Heerikhuizen, H.; Vreugdenhil, E.; Geraerts, W.P. Co-evolution of ligand-receptor pairs in the vasopressin/oxytocin superfamily of bioactive peptides. J. Biol. Chem. 1996, 271, 3619-3626. [CrossRef]

26. Pateraki, L.E.; Stratakis, E. Synthesis and organization of vitellogenin and vitellin molecules from the land crab Potamon potamios. Comp. Biochem. Physiol. B Biochem. Mol. Biol. 2000, 125, 53-61. [CrossRef]

27. Panouse, J.B. L'action de la glande du sinus sur I'ovaire chez crevette Leander serratus. C. R. Acad. Sci. Paris 1944, 218, 292-294.

28. Soyez, D.; Van Deijnen, J.E.; Martin, M. Isolation and characterization of a vitellogenesis-inhibiting factor from sinus glands of the lobster, Homarus americanus. J. Exp. Zool. A Ecol. Gen. Physiol. 1987, 244, 479-484. [CrossRef]

29. Zmora, N.; Chung, J.S. A novel hormone is required for the development of reproductive phenotypes in adult female crabs. Endocrinology 2014, 155, 230-239. [CrossRef]

30. Bao, C.C.; Yang, Y.N.; Huang, H.Y.; Ye, H.H. Inhibitory role of mud crab short neuropeptide F in vitellogenesis and ovarian maturation via autocrine/paracrine signaling. Front. Endocrinol. 2018, 9, 390-401. [CrossRef]

31. Liu, A.; Liu, F.; Shi, W.Y.; Huang, H.Y.; Wang, G.Z.; Ye, H.H. C-type allatostatin and its putative receptor from the mud crab serve an inhibitory role in ovarian development. J. Exp. Biol. 2019, 222, jeb207985. [CrossRef] [PubMed]

32. Ostrowski, J.; Kjelsberg, M.A.; Caron, M.G.; Lefkowitz, R.J. Mutagenesis of the beta2-adrenergic receptor: How structure elucidates function. Annu. Rev. Pharmacol. Toxicol. 1992, 32, 167-183. [CrossRef] [PubMed] 
33. Cruz, L.J.; De Santos, V.; Zafaralla, G.C.; Ramilo, C.A.; Zeikus, R.; Gray, W.R.; Olivera, B.M. Invertebrate vasopressin/oxytocin homologs. Characterization of peptides from Conus geographus and Conus striatus venoms. J. Biol. Chem. 1987, 262, 15821-15824. [PubMed]

34. Venkatesh, B.; Si-Hoe, S.L.; Murphy, D.; Brenner, S. Transgenic rats reveal functional conservation of regulatory controls between the Fugu isotocin and rat oxytocin genes. Proc. Natl. Acad. Sci. USA 1997, 94, 12462-12466. [CrossRef]

35. Gruber, C.W.; Koehbach, J.; Muttenthaler, M. Exploring bioactive peptides from natural sources for oxytocin and vasopressin drug discovery. Future Med. Chem. 2012, 4, 1791-1798. [CrossRef]

36. Glenner, H.; Thomsen, P.F.; Hebsgaard, M.B.; Sørensen, M.V.; Willerslev, E. The origin of insects. Science 2006, 314, 1883-1884. [CrossRef]

37. Dohlman, H.G.; Caron, M.G.; DeBlasi, A.; Frielle, T.; Lefkowitz, R.J. Role of extracellular disulphide bonded cysteines in the ligand binding function of the beta2-adrenergic receptor. Biochemistry 1990, 29, 2335-2342. [CrossRef]

38. Holmgren, S.; Jensen, J. Evolution of vertebrate neuropeptides. Brain Res. Bull. 2001, 55, 723-735. [CrossRef]

39. Mizuno, J.; Takeda, N. Phylogenetic study of the oxytocin-like immunoreactive system in invertebrates. Comp. Biochem. Physiol. A Physiol. 1988, 91, 733-738. [CrossRef]

40. Mizuno, J.; Takeda, N. Phylogenetic study of the arginine-vasotocin/arginine-vasopressin-like immunoreactive system in invertebrates. Comp. Biochem. Physiol. A Physiol. 1988, 91, 739-747. [CrossRef]

41. Akiko, K.; Naoto, M.; Hiroki, T.; Sean, M.; Minoru, M.; Takayoshi, O.; Masayuki, M.; Laurent, K. Oxytocin/vasopressin-like peptide inotocin regulates cuticular hydrocarbon synthesis and water balancing in ants. Proc. Natl. Acad. Sci. USA 2019, 116, 5597-5606.

42. Takuwa-Kuroda, K.; Iwakoshi-Ukena, E.; Kanda, A.; Minakata, H. Octopus, which owns the most advanced brain in invertebrates, has two members of vasopressin/oxytocin superfamily as in vertebrates. Regul. Pept. 2003, 115, 139-149. [CrossRef]

43. Spanings-Pierrot, C.; Soyez, D.; Van Herp, F.; Gompel, M.; Skaret, G.; Grousset, E.; Charmantier, G. Involvement of crustacean hyperglycemic hormone in the control of gill ion transport in the crab Pachygrapsus marmoratus. Gen. Comp. Endocrinol. 2000, 119, 340-350. [CrossRef] [PubMed]

44. Serrano, L.; Blanvillain, G.; Soyez, D.; Charmantier, G.; Grousset, E.; Aujoulat, F.; Spanings-Pierrot, C. Putative involvement of crustacean hyperglycemic hormone isoforms in the neuroendocrine mediation of osmoregulation in the crayfish Astacus leptodactylus. J. Exp. Biol. 2003, 206, 979-988. [CrossRef] [PubMed]

45. Urlacher, E.; Soustelle, L.; Parmentier, M.L.; Verlinden,H.; Gherardi, M.J.; Fourmy, D.; Mercer, A.; Devaud, J.M.; Massou, I. Honey bee allatostatins target galanin/somatostatin-like receptors and modulate learning: A conserved function? PLoS ONE 2016, 11, e0146248. [CrossRef]

46. Urlacher, E.; Devaud, J.M.; Mercer, A.R. C-type allatostatins mimic stress-related effects of alarm pheromone on honey bee learning and memory recall. PLOS ONE 2017, 12, e0174321. [CrossRef]

47. Sandeman, D.; Sandeman, R.; Derby, C.; Schmidt, M. Morphology of the brain of crayfish, crabs, and spiny lobsters: A common nomenclature for homologous structures. Biol. Bull. 1992, 183, 304-326. [CrossRef]

48. Shu, L.; Yang, Y.N.; Jiang, Q.L.; Huang, H.Y.; Ye, H.H. Does the bone morphogenetic protein 7 inhibit oocyte maturation by autocrine/paracrine in mud crab? Gen. Comp. Endocrinol. 2018, 266, 119-125.

49. Sirotkin, A.V.; Gerasimova, G.G.; Golubev, A.K.; Dmitriev, V.B. The effect of arginine vasotocin on the production of steroid hormones by mouse, cow and chicken ovarian tissues in vitro. Biomed. Sci. 1990, 1, 308-310.

50. Sirotkin, A.V.; Nitray, J.; Tarasenko, L.W.; Uhrin, P.; Laurinčik, J.; Bulla, J. Effects of oxytocin, vasopressin and vasotocin and their agonists on steroid secretion by bovine granulosa cells. Anim. Reprod. Sci. 1995, 39, 81-87. [CrossRef]

51. Sirotkin, A.V.; Schaeffer, H.J.; Mlyncek, M.; Missik, J.; Bulla, J. Oxytocin affects the release of steroids, insulin-like growth factor-I, prostaglandin F2a and cyclic nucleotides by human granulose cells in vitro. Hum. Reprod. 1996, 11, 152-155. [CrossRef] [PubMed]

52. Singh, V.; Joy, K.P. Vasotocin induces final oocyte maturation and ovulation through production of a maturation-inducing steroid in the catfish Heteropneustes fossilis. Gen. Comp. Endocrinol. 2011, 174, 15-21. [CrossRef] [PubMed] 
53. Banerjee, P.; Chaube, R.; Joy, K.P. In situ localization of vasotocin and isotocin precursor mRNA in brain and ovary of the catfish Heteropneustes fossilis and estrogen regulation of the gene expression. J. Transl. Neurosci. 2016, 1, 1-10.

54. Singh, V.; Joy, K.P. Relative in vitro seasonal effects of vasotocin and isotocin on ovarian steroid hormone levels in the catfish Heteropneustes fossilis. Gen. Comp. Endocrinol. 2009, 162, 257-264. [CrossRef] [PubMed]

55. Joy, K.P.; Singh, V. Functional interactions between vasotocin and prostaglandins during final oocyte maturation and ovulation in the catfish Heteropneustes fossilis. Gen. Comp. Endocrinol. 2013, 186, 126-135. [CrossRef] [PubMed]

56. Jeng, S.S.; Wan, W.C.; Chang, C.F. Existence of an estrogen-like compound in the ovary of the shrimp, Parapenaeus fissures. Gen. Comp. Endocrinol. 1978, 36, 211-214. [CrossRef]

57. Thongbuakaew, T.; Siangcham, T.; Suwansa-ard, S.; Elizur, A.; Cummins, S.F.; Sobhon, P.; Sretarugsa, P. Steroids and genes related to steroid biosynthesis in the female giant freshwater prawn, Macrobrachium rosenbergii. Steroids 2016, 107, 149-160. [CrossRef]

58. Fairs, N.J.; Quinlan, P.T.; Goad, L.J. Changes in ovarian unconjugated and conjugated steroid titers during vitellogenesis in Penaeus monodon. Aquaculture 1990, 89, 83-99. [CrossRef]

59. Swevers, L.; Lambert, J.G.; de Loof, A. Synthesis and metabolism of vertebrate-type steroids by tissues of insects: A critical evaluation. Experientia 1991, 47, 687-698. [CrossRef]

60. Summavielle, T.; Monteiro, P.; Reis-Henriques, M.; Coimbra, J. In vitro metabolism of steroid hormones by ovary and hepatopancreas of the crustacean penaeid shrimp Marsupenaeus japonicus. Sci. Mar. 2003, 67, 299-306. [CrossRef]

61. Lin, J.L.; Shi, X.; Fang, S.B.; Zhang, Y.; You, C.H.; Ma, H.Y.; Lin, F. Comparative transcriptome analysis combining SMRT and NGS sequencing provides novel insights into sex difffferentiation and development in mud crab (Scylla paramamosain). Aquaculture 2019, 513, 734447. [CrossRef]

62. Warrier, S.R.; Tirumalai, R.; Subramoniam, T. Occurrence of vertebrate steroids, estradiol $17 \beta$ and progesterone in the reproducing females of the mud crab Scylla serrata. Comp. Biochem. Physiol. A Mol. Integr. Physiol. 2001, 130, 283-294. [CrossRef]

63. Huang, X.S.; Ye, H.H.; Huang, H.Y.; Yang, Y.N.; Gong, J. An insulin-like androgenic gland hormone gene in the mud crab, Scylla paramamosain, extensively expressed and involved in the processes of growth and femalereproduction. Gen. Comp. Endocrinol. 2014, 204, 229-238. [CrossRef] [PubMed]

64. Wang, Y.L.; Chen, Y.D.; Han, K.H.; Zou, Z.H.; Zhang, Z.P. A vasa gene from green mud crab Scylla paramamosain and its expression during gonadal development and gametogenesis. Mol. Biol. Rep. 2012, 39, 4327-4335. [CrossRef] [PubMed]

(C) 2020 by the authors. Licensee MDPI, Basel, Switzerland. This article is an open access article distributed under the terms and conditions of the Creative Commons Attribution (CC BY) license (http://creativecommons.org/licenses/by/4.0/). 